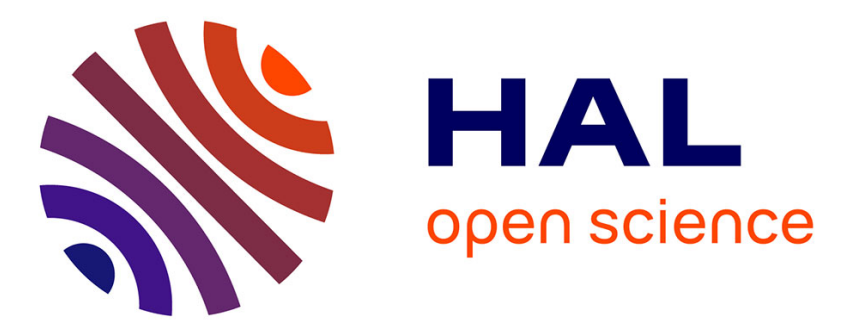

\title{
William Stanley Jevons' The Coal Question (1865), beyond the rebound effect
}

\author{
Antoine Missemer
}

\section{To cite this version:}

Antoine Missemer. William Stanley Jevons' The Coal Question (1865), beyond the rebound effect. Ecological Economics, 2012, 82, pp.97-103. 10.1016/j.ecolecon.2012.07.010 . halshs-00738258

\section{HAL Id: halshs-00738258 \\ https://shs.hal.science/halshs-00738258}

Submitted on 24 May 2016

HAL is a multi-disciplinary open access archive for the deposit and dissemination of scientific research documents, whether they are published or not. The documents may come from teaching and research institutions in France or abroad, or from public or private research centers.
L'archive ouverte pluridisciplinaire HAL, est destinée au dépôt et à la diffusion de documents scientifiques de niveau recherche, publiés ou non, émanant des établissements d'enseignement et de recherche français ou étrangers, des laboratoires publics ou privés.

\section{(1) (1) $\$$}

Distributed under a Creative Commons Attribution - NonCommercial - NoDerivatives| 4.0 


\title{
William Stanley Jevons' The Coal Question (1865), BEYOND THE REBOUND EFFECT
}

\begin{abstract}
Antoine MisSEMER ${ }^{*}$
Reference (to cite the paper):

Missemer, Antoine. 2012. "William Stanley Jevons' The Coal Question (1865), beyond the rebound effect". Ecological Economics, vol. 82, p. 97-103.

[http://dx.doi.org/10.1016/j.ecolecon.2012.07.010]

The pages of the published version are indicated in the margins.

Abstract

Before his major 1870s economic writings, William Stanley Jevons wrote in 1865 his first important book entitled The Coal Question. Jevons displays an interest for the problem of resource depletion, and some opportunism linked to the treatment of a subject in vogue at the time. The Coal Question is retrospectively essentially known for having pointed out the first bases of what we call today the rebound effect, known as well as the "Jevons' paradox". No one can deny the major contribution Jevons did by insisting on the energy efficiency paradoxical phenomenon. However, this is not the only interesting idea proposed in The Coal Question. This article aims at drawing a larger framework of the ideas developed by Jevons, looking at some specific points that testify to his position as a turning point in the history of environmental studies. We see that Jevons expresses a desire of emancipation from both natural sciences and engineering, yet without ignoring the necessity of interdisciplinary perspectives to deal with environmental matters. It places Jevons as a pioneer of several modern approaches towards environmental economics, including ecological economics.
\end{abstract}

\footnotetext{
* [In 2012] Centre Walras-Pareto, University of Lausanne, Internef, CH-1015 Lausanne-Dorigny \& Triangle, University of Lyon 2, ISH, 14 av. Berthelot, F-69007 Lyon. Email address: antoine.missemer@unil.ch
} 


\section{Introduction}

While environmental economics tries to play a part on the academic stage to renew social sciences scholars' view on human societies, the history of environmental economics is only at an embryonic stage. Both environmental economists and historians of economic thought look at it with some ambivalent feelings, and suspicion towards a narrow sub-discipline that could not go very far in the past because of the contemporaneity of the subject it deals with. Actually, as it is currently more and more recognized, environmental preoccupations in the economic field are not new, and one is able to guess that our modern challenge with regard to sustainable development could often find echo in problems already encountered in the past. Natural resource depletion issues have been addressed at different stages during the long economic history, and one of those steps concerns the depletion of coal, when the second part of the Industrial Revolution took place. William Stanley Jevons was one of the great intellectuals of the time who focused his attention on that concern (The Coal Question, first ed. 1865, second ed. 1866).

The Coal Question is a book often considered as chiefly empirical and not really worthy of interest compared to Jevons' later Theory of Political Economy (1871). In his classic book, William Stanley Jevons and the Making of Modern Economics (2005), Harro Maas underlines briefly the role of The Coal Question in Jevons' career ${ }^{1}$ (Maas, 2005: 33, 125-6). The strict border Jevons erected between, on one side, his contributions to economic theory - Jevons clearly is a major pioneer of the Marginalist Revolution - and, on the other, his empirical works on resource depletion and climate, seems to legitimate this undervalued judgment, although some authors tried to interpret

\footnotetext{
${ }^{1}$ Maas highlights some elements in The Coal Question that would deserve attention, as Jevons' energetics: "[his works] are to be understood in relation to his engagement with the debates over the conservation of energy in the 1860s. Jevons's Coal Question (1865), which was somewhat of a hit in his own day, serves as major source in this regard. But even without such a detailed analysis, it might seem obvious that Jevons's energy came from energy physics" (Maas, 2005: 7). Our wish is to move from this synchronic debate about the role of The Coal Question in Jevons' work to a diachronic debate about its role in the history of environmental studies.
}

Jevons' analysis of coal depletion through his marginalist theory (Martinez-Alier, 1987: 160-2). Of course his empirical works were written first but Jevons continued to refer to The Coal Question on several occasions during the 1870s (Jevons, 1875), doing so without making any link with his then more recent research. That desire to categorise his different works often appears with his political philosophy and his economic theory (SekerlerRichiardi, 2010: 71-2). By insisting only on his contribution to marginalism, historians of economic thought used that strict divide and neglected a large part of Jevons' ideas. Nevertheless that does not prevent one's interest to focus on that part, and more precisely on the ideas dedicated to the resource depletion issue.

Until recently, and thanks to the foundation it laid to the rebound effect, The Coal Question was the subject of renewed attention from ecological economists (Jevons, 1866b, 1867: 26). A rebound effect happens when an energy efficient technology is implemented instead of an old one, and when it creates an opposite effect to what could be expected: the new technology does not reduce the total quantity of energy consumed, but increases it. Being more efficient, it cheapens the energy costs and calls for larger uses. On the macroeconomic stage, the new technology not only does not solve the energy scarcity issue, but it also may even make it worse. This phenomenon, well known as the "Jevons' paradox" (Alcott, 2005; Sorrell, 2009), gave birth to a small literature concerning Jevons (see for instance Alcott, 2005; Clark and Foster, 2001; Robine, 1990) and to a larger one concerning rebound effect as a technical concept (for a survey see Greening et al., 2000; Madlener and Alcott, 2009; van den Bergh, 2011). To go further than Jevons' rebound effect, not much literature is available except White's remarkable paper on the institutional environment of Jevons' writing in the 1860s (White, 1991). It is quite unfortunate because The Coal Question contains many original ideas besides the rebound effect. This article aims at pointing out a certain number of them that reveal themselves useful for the ecology-economy-society matrix so dear to modern ecological economists. We suggest that those ideas constitute an early starting point in different fields of environmental studies. On the one hand, they give birth to an economic approach emancipated from other disciplines, paving the way for conventional environmental economics. And on the other, they 
testify to the necessity of transversal approaches into natural resources studies, a concern shared by ecological economics.

After the first introductory section, we focus on the historical context surrounding The Coal Question (Section 2). Therefore we are able to understand the full content of the book by discussing the great themes developed by Jevons and leading to the resource depletion issue. As will be shown, Jevons considered the depletion problem as an economic problem because of the possible redefinition of Britain's place in the international competitive markets (Section 3). In order, not to solve the depletion issue, which for him is not solvable, but to avoid a relative decline, Jevons proposed a social principle that looks like an intergenerational compensation principle similar to the weak sustainability concept (Section 4) that leads us to look at the role attributed to government regulation in the resource depletion issue (Section 5). This analysis ends with some comments and concluding remarks (Section 6).

\section{The Coal Question in Its Historical Context}

After a first and long statistical work produced in 1863-1864 about the evolution of prices in Britain from the end of the 18th century, to launch his new project on coal Jevons decided, in June 1864 , to come back to London, where he had been a student (Black and Könekamp, 1972: 43). He conceived that project as a point of convergence between his interests both in political economy and in mathematical statistics. Within a year, Jevons wrote The Coal Question; he published it with the personal support of Alexander MacMillan, in April 1865. Unlike what that short period might suggest, the redaction of the manuscript was not easy for Jevons, notably because of the huge quantity of data needed. This thick book had a clear ambition: to give his author the reputation he did not yet have, thanks to a subject fashionable during the 1860 s in Britain. Jevons did not hide his opportunistic motivations, as he wrote to his brother in February 1864:

“[...] I am going on with various work. I am nearly completing the full reduction of prices since 1782 which will show many things of interest I think. I am also about undertaking the Subject of the exhaustion of Coal in England which I believe is a very serious matter. A good publication on the subject would draw a good deal of attention. I am convinced that it is necessary for the present at any rate to write on popular subjects. My logic has made no noise although it is somewhat favourably regarded by De Morgan, Prof. Sandeman here, \& others who know what Logic is or should be [...]." (Jevons, 1864: 52).

Unfortunately, the book initially failed to find a readership and all of Jevons' pugnacity did not turn round this initial tendency.

However, slowly, Jevons' expectations were fulfilled, at the end of 1865 , thanks to the support of great intellectuals like Sir John Herschel. ${ }^{2}$ Sir John Herschel seems to have played an important role in the diffusion of the book, since Jevons was very grateful to him for his support (Black, 1977a: 77, 80; Black and Könekamp, 1972: 200-1). During the winter and the spring of 1866, The Coal Question eventually became a best seller in the political, intellectual, and industrial spheres of Victorian Britain (White, 1991: 289). That success called for a second edition during the summer of 1866 , an edition preceded by a foreword Jevons wrote to answer some of the criticisms he had already faced, notably on his so called pessimistic view of the future.

Since February 1866, some months before this second edition, Jevons became aware of the impact of his writing when he received via his publisher a letter from Gladstone, then Chancellor of the Exchequer (Black, 1977a: 84; Black and Könekamp, 1972: 202-3). In his letter, Gladstone congratulates Jevons for his work and expresses interest for the fiscal aspects of Jevons' arguments, some arguments on which we will come back later (Section 4):

"I am not certain whether I owe to your kindness, or to that of Mr Jevons, my early opportunity of perusing his work on coal: but I have perused it with care, and with extraordinary interest. It makes a deep impression upon me, and strengthens the convictions I have long entertained, but with an ever growing force, as to our duty with regard to the National Debt." (Gladstone, 1866: 203).

What is interesting is to measure how much the

\footnotetext{
${ }^{2}$ Sir John Herschel (1792-1871) was a famous scientist of Victorian Britain, whose influence among the intellectual and political spheres of the time was undeniable.
} 
political world created a springboard for Jevons' fame. It did so by using an extra-budget argument (resource depletion) to legitimate a fiscal policy that was already in the mind of some politicians (White, 1991: 298). That was not necessarily Jevons' initial goal but it helped him spread his influence, even on J-S. Mill who gave his support to Jevons, by quoting him in the House of Commons during a debate on malt duty on April 17, 1866 (Maas, 2005: 33; Mill, 1866). Jevons' success therefore reached its climax during the summer of 1866 , by the appointment of a Royal Commission on the coal question, which sat until the beginning of the 1870s (Price-Williams, 1889: 2 ), under the distant and occasional supervisory control of its indirect initiator (Black, 1977a: 154). Then Jevons decided to minimise his interventions on the subject and not to intervene in the political debate; as he wrote to Herschel in June 1866:

"Now that a Royal Commission is to be appointed the subject must be left very much to them. Whatever becomes of any particular views - it is not to be doubted I think that good must come out of an inquiry into the use of such an article as Coal. [...]" (Jevons, 1866a: 123).

However, he never totally forgot the ideas he had submitted in The Coal Question, as some comments he did later in the 1870s and in the beginning of the 1880s testify (Black, 1977b: 143).

\section{Resource Depletion as an Economic Problem}

\subsection{An Economic Definition of Exhaustion}

Jevons' ideas are presented in The Coal Question in a remarkable way, with a well-built argumentative discourse, as Georgescu-Roegen noticed almost a century later. He was surprised to discover in Jevons' work both an articulated argument on resource depletion and a major contribution to standard economic theory (Georgescu-Roegen, 1978: 353f). Coal depletion became a worrying subject in the middle of the 19th century, when British observers discovered a striking contrast between a decreasing number of new exploited mines and a rising demand for coal. British economic development had been laid on the quality and cheap coal from Wales exploited in a very intensive way (Jevons, 1868: 29-30; Robine, 1990: 374). While those mines were depleting, geologists such as Hull, Binney or Godwin-Austen (Black, 1977a: 63; Hull, 1861), and then economists such as Jevons tried to warn the political decision-makers that time had come to realise what coal depletion would mean for British industry and the development of British economy: a slow-down in economic activity, or even a complete stand-still. In The Coal Question, Jevons underlines that beyond the limited quantity of coal available, the real problem was the consumption rate of coal. Should this rate be linear, Britain would certainly have time to be concerned about resource depletion, whatever the level of reserves. But when taking into account the fact that the rate is not linear, but exponential, time constraints and resource depletion become a very serious issue:

"But whether this estimate be accurate or not, it will appear that the exact quantity of coal existing is a less important point in this question than the rate at which our consumption increases, and the natural laws which govern that consumption. [...]" (Jevons, 1866b: 26).

Note that Jevons talks about "natural laws", an important idea in the marginalist matrix of thought. ${ }^{3}$ It reinforces the immutable aspect of resource depletion to which Britain faces.

Going further than the simple observation of resource depletion, Jevons suggests a definition of exhaustion that at first sight might be surprising. For him, an economist must distinguish the physical from the economic forms of exhaustion. Physical availability of resources (technically exploitable coal) is not the same as economic availability (coal exploitable at reasonable costs). What interests Jevons is the latter form of availability. Absolute physical coal exhaustion is nonsense for him. Britain possesses large coalfields not yet exploited, and other countries have huge coalfields that could - if necessary - feed international markets. If coal depletion is a subject of concern, it is because it generates a process of price rises, which would spread through all economic activities, damage Britain's

\footnotetext{
${ }^{3}$ Natural laws appear in the English marginalists' system as a preliminary to economic reasoning. They provide a frame in which economic theories evolve. It is in that sense for instance that the English marginalists appeal to psycho-physiology to point out the natural "subtle feelings of the human heart" (Jevons, 1877: 736) that in an exogenous way command economic behaviours (see Chaigneau, 2002).
} 
competitiveness, and impoverish large parts of the population (Jevons, 1866b: 82-4). Jevons uses an idea already developed by Armstrong in 1863 according to which resource depletion produces a rise of energy prices and weakens British prosperity based on cheap and good quality coal (Armstrong, 1863; Jevons, 1866b: 31-2; Robine, 1990: 371-2, 385; White, 1991: 291).

Therefore exhaustion is considered in The Coal Question in its precise economic sense. That allows Jevons to focus his attention on his own field of research, leaving the reserves amount question to geologists. To his view, resource depletion needs to be understood as an economic issue, and nothing else:

"The expression 'exhaustion of our coal mines' states the subject in the briefest form, but is sure to convey erroneous notions to those who do not reflect upon the long series of changes in our industrial condition [...]. Many persons perhaps entertain a vague notion that some day our coal seams will be found emptied to the bottom [...]. It is almost needless to say, however, that our mines are literally inexhaustible. We cannot [economically and technically] get to the bottom of them; and though we may some day have to pay dear for fuel, it will never be positively wanting." (Jevons, 1866b: v-vi).

At the time Jevons was writing, Britain possessed the highest quality of coal available on the international markets, thanks to its Welsh coalfields producing a good ore for all industrial uses (Fine, 1990). Combined with British industrial assets and commercial powers, that advantage allowed Britain to reach a clear industrial supremacy. But as Jevons notices, that supremacy relied nearly exclusively on its good quality and cheap coal. With the exhaustion of coal, Britain would become less competitive and might face new competitors such as the United States or Australia, which still had huge virgin reserves. The increase of local prices would not be the only exhaustion transmission channel to British prosperity. Because Britain tends to finance its imports of food by its exports of coal, a competitive loss would mean a weakening of British people's health, increasing poverty and misery among the population (Jevons, 1868: 24; White, 1991: 291).

\subsection{The Insufficiency of the Technological Solutions}

In his essay, Jevons gauges the validity of the solutions advanced by some of his contemporaries to minimise the risks resource depletion would imply. Quite pessimistic on this point, Jevons emphasises the immutable nature of coal depletion. It is within that frame that he develops the bases of his rebound effect. Our purpose is not to analyse this well-known contribution to modern environmental economics. All we need to add is that the remarkable aspect of this contribution relates to its completeness: Jevons points out not only what Greening et al. call the microeconomic "direct rebound effect" (Greening et al., 2000: 390) which corresponds to the one already introduced (Section 1), but also its other forms (secondary effects, macroeconomic scale effects, etc.). One encounters those latter forms when, for instance, energy efficiency may increase not only the consumption of the goods or services concerned by the improvement, but also of the goods or services that are not directly affected by the energy efficiency gain, the demand of which is increased by the income effect experienced by consumers:

"[...] The inventor who can bring a new and economical air-engine into use will reap a fortune to be counted by millions, and will gain the rank of a second Watt. But such an improvement of the engine, when effected, will only accelerate anew the consumption of coal. [...]" (Jevons, 1866b: 132-3).

"[...] In fact, there is hardly a single use of fuel in which a little care, ingenuity, or expenditure of capital may not make a considerable saving. But no one must suppose that coal thus saved is spared - it is only saved from one use to be employed in others, and the profits gained soon lead to extended employment in many new forms. The several branches of industry are closely interdependent, and the progress of any one leads to the progress of nearly all." (Jevons, 1866b: 136).

By giving to his challengers an explanation for the many weaknesses of the technological solutions to resource depletion issues, through the rebound effect, Jevons laid the stepping-stone for the emancipation of environmental economics from engineering. Mechanical energy efficiency will not solve coal depletion, because several economic processes (prices, demand bias) will cancel the positive technical advances. Hence we understand 
why this is the main contribution posterity retained from The Coal Question. Nevertheless, it is not the only road Jevons takes to measure the solutions commonly advocated against coal depletion. He also discusses the question of the possible existence of substitutes for coal.

As emphasized in our concluding remarks (Section 6), it is certainly on that particular point that Jevons made a mistake by considering that no substitute for coal was available. He dedicates several passages of his book to that question, looking for alternative available sources of energy or about to be so at the time. Wood, waterpower and oil seem to him not efficient enough to produce a quantity of energy equivalent to coal (Jevons, 1866b: 163-4; 1867: 18-9). It is not insignificant if people got rid of wood and used coal instead. And oil still needs energy to be extracted and transformed into expendable forms. That energy necessary comes from coal. He admits that electricity is more promising, but for him there is a logical problem: electricity is not a source of energy but only an energy vehicle. In other words, one needs to produce electricity from something, basically from coal. Hence to trust electricity would lead to the same mistakes people made in former times about perpetual motion:

"[...] Electricity, in short, is to the present age what the perpetual motion was to an age not far removed. People are so astonished at the subtle manifestations of electric power, that they think the more miraculous effects they anticipate from it the more profound the appreciation of its nature they show. But then they generally take that one step too much which the contrivers of the perpetual motion took - they treat electricity not only as a marvellous mode of distributing power, they treat it as a source of self-creating power. [...] to think of getting force except from some natural source, is as absurd as to think of making iron or gold out of vacant space." (Jevons, 1866b: 140-1).

Thus electricity does not solve the depletion issue; it faces a scarcity problem by way of the natural resources used to produce it (Peart, 1996: 24). The remaining energy sources were just outlined at his time, such as solar power for instance. In writings around The Coal Question itself, Jevons considers solar power as an interesting alternative to coal. However, at the time of writing, it could not be technically mastered. Moreover, and this is Jevons' key argument about the limits of solar power (Black, 1977a: 91; Jevons,
1868: 34-5), Britain is certainly not the bestendowed country with sunshine! In modern terms, solar power could partially solve the resources exhaustion in its physical sense, but not its economic components - British competitiveness is after all Jevons' central concern.

As a whole, for Jevons, substitutes are not a promising solution to coal depletion. One day, maybe, one would find a technological breakdown enabling to get around exhaustion. But it is not likely to happen anytime soon according to Jevons. The current depletion issue, which threatens British prosperity, will thus remain a problem for many years (Black, 1977a: 90-1; Jevons, 1866b: 165-8).

By treating exhaustion as an economic problem, both on the definition of depletion and on the reasoning method used to evaluate the common solutions advocated, Jevons appears as a pioneer of contemporary environmental economics. He participated in the emancipation of environmental economics from natural sciences such as geology on the one hand (because he focused on the consumption rate and not on the physical reserves), and from engineering on the other (because he doubted the effectiveness of technical innovations to treat depletion). His solution to prevent populations from suffering from lower living standards then goes one step further: it leads him to deal with intergenerational equity.

\section{The Intergenerational Compensation Principle}

Jevons' contribution to resource depletion management shifts the solutions advocated from the economic and technical to the social and political domain. The intuition behind this shift is linked to the long-term effects of coal depletion. Rises of prices on local markets and competitive decline for foreign exchanges are two consequences of exhaustion that concern not only the current British people but also future generations. If we consider that natural resources are not necessarily the property of one generation, in a utilitarian way of conceiving social justice (Jevons, 1871: 27-32), depleting coal today rather than tomorrow raises intergenerational equity issues (Jevons, 1866b: xxii). It could prevent future generations to satisfy their needs, or at least to maintain their march towards progress. Coal depletion is inevitable because British development almost exclusively 
rests upon coal industry. But its consequences are not totally unavoidable. Indeed, as Jevons explains, intergenerational equity must not lead to guilt or fatalism. It should only appeal to responsibility. It thus consists in making sound uses of available resources to promote education, capital investment and public facilities. As Jevons notices during a lecture given at Carpenters' Hall in Manchester, in January 1867 , those are things present generations can leave to future generations:

"[...] It strikes me that the best way to prepare for future time is by taking every advantage of the present. I do not think that our descendants will blame us if we take proper precautions to use our coal economically, and to get the best possible return for it - that is to say, the most force and the most wealth, and not to burn it needlessly upon waste heaps, as is sometimes done. [...] We must use our wealth as it ought to be used. If we use it in mere luxury and mismanagement, such as in our dockyards, we shall be justly blamed; but if we use it in improving the condition of every one, so far as it can be improved if we use it in providing education, in improving the dwellings; and if we could by any possibility use it so as to do away with pauperism, and to provide libraries and institutions or anything that will increase the power and improve the character of our people, then I think we shall never be blamed for using our coal too fast. [...]" (Jevons, 1867: 27-8).

Expounded like this, Jevons' position looks like an intergenerational compensation principle. The present generations are allowed to use intensively ore resources to the extent they transform them in wealth for future generations. These generations therefore will not have access to cheap and good quality coal any longer, but they will benefit from new infrastructures and better knowledge instead. Even if the vocabulary used by Jevons is not the same, we may perceive an analogy between Jevons' infrastructures-resources compensation and the physical capital-natural capital compensation argued by the modern providers of weak sustainability: the criterion for sustainability simply rests upon the maintenance, in the long run, of the total stock of capital, including physical, human and natural capitals (see among others Gowdy and O'Hara, 1997; Pearce, 1997; Pearce and Atkinson, 1993; Pearce et al., 1994; Venkatachalam, 2007). The theoretical foundations of Jevons' and weak sustainability arguments are not the same: infrastructures and resources are conditions for British prosperity on a macro scale while capitals are seen as inputs of the economic activities on a micro scale. Jevons' idea is wider than that advocated by the weak sustainability promoters, because it carries a philosophical vision of society much more complete than a mere technical treatment of a problem. Jevons' view includes a commitment to progress, in particular through the education of population. This is in line with the 19th century economic tradition according to which education is fundamental, James Mill certainly being the most representative character in that tradition (Bianchini, 2011). Thus the intergenerational compensation principle in its Jevonsian version is not exactly the same as the one usually advocated today.

The proposition stated in The Coal Question does not end up here. Jevons focuses in a specific way to compensate future depletion, through the fiscal argument which attracted Gladstone's interest. For Jevons, one of the main levers available for present generations to make a sound use of natural resources is public debt (Jevons, 1866b: 367). Indeed, that debt constitutes a collective burden which, if one reconstructs Jevons' line of thought, deteriorates future generations' situation: not only those generations will suffer a lack of natural resources, but moreover also part of them will have to support taxes, to repay the public debt. This double punishment cannot be tolerated if we care about intergenerational equity. One way to correct this phenomenon is therefore to use today's wealth resulting from the exploitation of cheap and good quality coal to repay at least a part of the current public debt:

"The only suggestion I can make towards compensating posterity for our present lavish use of cheap coal is one that it requires some boldness to make. I mean the reduction or paying off of the National Debt. [...] An annual appropriation towards the reduction of the debt would serve the three purposes of adding to the productive capital of the country, of slightly checking our present too rapid progress, and of lessening the future difficulties of the country." (Jevons, 1866b: 364$5)$.

We may well understand why that fiscal argument has been picked up by politicians during Jevons' time to mitigate tax reductions often claimed in the tradition of the repeal of the Corn Laws (Black, 1981: 15; White, 1991). From the intergenerational equity point of view, reducing public debt is then indirectly the best mean for 
finding economic resources in order to develop future productive capacities. As Jevons writes, it nevertheless needs "some boldness". One will notice in addition the second advantage of reducing debt underlined in the quotation above: it ought to slacken the pace of development, by restricting present available financial resources. This slowing down enables a delayed depletion, thus a delayed increase in coal prices, which may be beneficial. Such a process is only a secondary effect of debt reduction; Jevons does not hint at a voluntary obstacle to progress that present generations should impose to themselves - it would be contradictory with his claim for a universal right to prosperity (Jevons, 1868: 35) - but he merely describes a way of slowing down the march of progress in the long run.

The intergenerational compensation principle was at this time a very innovative idea. It witnesses a move from what Jevons considers inefficient technological or economic solutions to a subtle bypassing mechanism of the problem. Moreover, by insisting on the public debt lever, Jevons appeals to indirect government intervention that raises the question of collective regulation to manage resource depletion.

\section{Government Regulations and Resource Depletion}

Even if Jevons' version of the intergenerational compensation principle implies government interventions in the management of resource depletion, it does not give it limitless powers. In Jevons' system of thought, government regulations are neither efficient, nor desirable, in all their forms, to solve the depletion issue, not solvable as such, as one may recall. In Jevons' time, the idea was common to introduce a kind of taxes or duties to control the production and the exports of coal. This idea was born at the beginning of the 19th century, and had been developed during the 1840s (see for instance Peel, 1842). It was consistent with the fight against the threats to British competitiveness that could result from coal depletion. Surprisingly, Jevons does not agree with this idea. In his view, government regulations, introduced to give a reasonable framework to coal consumption or coal exports in relation to depletion rate, cannot be efficient for two main reasons: (1) first, individual designs towards the pursuit of development are driven by a perpetual thirst for progress, which can hardly be curbed by regulatory obstacles (White, 1991: 292); (2) second, and this is a crucial point that makes usual government regulation (taxes, duties) undesirable: to the extent that coal is at the basis of all the industrial activities in Britain, taxing it to curb its uses would not only have results on the coal sector, but also on all the other industries, and eventually on the prices of all the goods and services produced in Britain:

"The rise in price of coal, whether from taxation or scarcity, must levy open and insidious contributions upon us in a manner with which no other tax whatever can compare. [...] through coal we shall be taxed in everything and at every moment. Our food will be taxed as it crosses the ocean, as it is landed by steam upon the wharf, as it is drawn away by the locomotive, as the corn is ground and the bread mixed and kneaded and baked by steam, and the meat is boiled and roasted by the kitchen fire. [...] Not an article of furniture or ornament [...] but is partly made by coal and will be taxed with it. And most things will be taxed over and over again at each stage of manufacture." (Jevons, 1866b: 361).

It would consequently damage British competitiveness on international markets and create the very difficulties that were supposed to be avoided. As a result, if Jevons' reasoning is extended, taxes and duties on ore resources do not solve anything but just anticipate the feared effects, and so without taking into account the practical checks which could prevent the regulators to implement their $\operatorname{tax}^{4}$ (Jevons, 1866b: 362). Chapter XVII of The Coal Question is thus dedicated to the different forms of common government regulations that could be advocated to examine coal depletion. Jevons concludes that the only effective collective action is the intergenerational compensation principle through the reduction of public debt.

Hence, government regulations have a specific status in Jevons' model. Standard regulations do not solve efficiently the depletion issue. However, one can hardly imagine a public debt reduction plan without government regulation. The point is not to challenge the legitimacy of government regulations

\footnotetext{
${ }^{4}$ One may notice that Jevons' arguments are close to those currently advocated against the introduction of a carbon tax (general inflation, practical checks), although the subject of concern is not the same: Jevons focuses on resource depletion whereas a carbon tax aims at reducing pollution.
} 
in the depletion domain, but merely to shift the regulation tool from economic incentives to political "boldness" on public debt.

\section{Concluding Remarks}

With The Coal Question, Jevons lays the first foundations to environ- mental economics. His book does not limit itself to the discovery of the rebound effect. In our opinion, three lessons can be drawn from Jevons' writing. First, from an epistemological point of view, Jevons appears in line with the economic tradition interested in natural resources. Here we mean that he put the depletion issue in an analytical framework, and not in an empirical one. He did so as Malthus did before for the two laws of population and food (Malthus, 1826, first ed. 1798), and as Hotelling for instance will do after him for the inter-temporal allocation of resources (Hotelling, 1931; MartinezAlier, 1987: 164-171). The point is not to measure precisely the amount of resources still available for exploitation, but to admit that a limit exists, and that it represents a threat for long-term prosperity (Gaudet, 1984: 273). When will the problems occur? This is not important; the main preoccupation is to know that they will occur. Hence, his topic is much more analytical than empirical:

"I may here notice that the exact amount of our stock of coal is not the matter of chief moment. The reader who thoroughly apprehends the natural law of growth, or multiplication in social affairs, will see that the absolute quantity of coal rather defines the height of wealth to which we shall rise, than the period during which we shall enjoy either the growth or the climax of prosperity." (Jevons, 1866b: 242).

Second, and maybe it is the most important lesson one may get from The Coal Question, Jevons seems to have perceived the different dimensions of ecological issues. Not only coal depletion is a natural problem to the extent physical reserves of a scarce resource exhaust, but it is also an economic problem due to the diffusion of coal among the various industrial sectors. Eventually, Jevons proposes an original solution to get around the disastrous consequences of ore exhaustion for British prosperity: the intergenerational compensation principle. Even if the main lever which is pointed up to introduce his principle is clearly economic (the reduction of public debt), it rests also on a social requirement for intergenerational equity. Jevons therefore puts together several dimensions of resource depletion and paves the way for transversal approaches to environmental matters, although his main worry future British competitiveness and prosperity remains purely economic (Clark and Foster, 2001: 96). We might however be slightly sceptical about Jevons' insistence on the public debt to deal with the consequences of depletion. Indeed, Jevons seems to neglect the real nature of public debt: by contracting debt, present generations do not leave only tax expenses to their descendants, but also incomes to creditors. Even if the distributive effects of those incomes need to be measured - the ones who repay the public debt are not always those who hold the bonds - the public debt cannot be only judged as a burden.

Third, the desire for emancipation formulated by Jevons from both natural sciences and engineering is a key element of the originality of Jevons' approach compared with his contemporary currents of thought. Whereas previous economists, when sensitive to natural issues, focused on agriculture (Malthus, 1820; Ricardo, 1821), Jevons broadens the question to mineral resources, and he does so with a distinct - properly economic - method independent of geologists' and engineers' methods (Hull, 1861). Hence Jevons' contribution is a starting point in environmental studies, as it had already been shown in other frameworks (MartinezAlier, 1987: 2). While one tends to consider economics as a perpetual second hand science always attracted by other scientific models as physics, biology or mathematics (Mirowski, 1989), one must admit that, in the environmental sphere, Jevons testifies to a wish of a demarcation-line, in order to delineate his own subject and his own method. However, for Jevons, the independence of environmental economics does not seem complete insofar as politics and ethics are kept in his system of thought. In that sense, ecological economists should be interested in The Coal Question because of their demand for a combining approach between ethics and economics that could find some echoes in Jevons's analysis. ${ }^{5}$

5 For instance, Martinez-Alier indicates that the allocation of exhaustible resources "cannot be separated from questions on moral values" (Martinez-Alier, 1987: 160). See also Martinez-Alier, 1987: 4, 156-7. 
One of the reasons why the history of economic thought did not refer to The Coal Question as much as to other contributions by Jevons is probably linked to the mistakes Jevons made in his evaluation of the possible futures solutions to coal depletion. His major mistake obviously is the refusal to admit that substitutes could be found and could be efficient if they were combined with technical progress (Clark and Foster, 2001: 94; Gaudet, 1984: 272, 274-5; Robine, 1990: 383). But as his son, Herbert Stanley Jevons, wrote in 1915, Jevons' mistake was only partial. At the turn of the 20th century, coal depletion indeed produced a relative decline for Britain, compared to the United States, for instance. If Jevons was wrong on the long run perspectives of resource depletion (at least until now), he did not fail to measure the results of coal depletion for the competitive structures of international markets. When a natural resource is at the foundation of the economic development of a country, future prosperity, or at least future competitiveness depends much on the availability of that resource. If no compensation is left to future generation, current generations' economic choices are made at the expense of generations to come. That leads Jevons to conclude his book by a phrase that reminds Georgescu-Roegen's 1975 "Energy and Economic Myths":

"The alternatives before us are simple. Our empire and race already comprise one-fifth of the world's population; and by our plantation of new states, by our guardianship of the seas, by our penetrating commerce, by the example of our just laws and firm constitution, and above all by the dissemination of our new arts, we stimulate the progress of mankind in a degree not to be measured. If we lavish and boldly push forward the creation and distribution of our riches, it is hard to overestimate the pitch of beneficial influence to which we may attain in the present. But the maintenance of such a position is physically impossible. We have to make the momentous choice between brief greatness and longer continued mediocrity." (Jevons, 1866b: 375-6).

Finally, with on the one hand the promotion of an intergenerational compensation principle that looks like the arguments dear to the defenders of

\footnotetext{
${ }^{6}$ Georgescu-Roegen writes: “[...] Perhaps, the destiny of man is to have a short, but fiery, exciting and extravagant life rather than a long, uneventful and vegetative existence. [...]" (Georgescu-Roegen, 1975: 379).
}

weak sustainability, and on the other a depletion issue taken as an immutable frame in which we analyse the ecology-economy-society system, Jevons is both a pioneer of conventional environmental economics and an initiator of ecological economics. His intuitions call for further works on government regulations and on the philosophical foundations of intergenerational equity. This is why he deserves all our attention with regard to the sustainability issues.

\section{Acknowledgments}

I would like to thank Nicolas Chaigneau for his comments on a previous version of this paper. I am also grateful to the members of the Centre WalrasPareto, in particular to Pascal Bridel, Nicolas Brisset and Maxime Desmarais-Tremblay, for their careful readings.

\section{References}

Alcott, B., 2005. Jevons' paradox. Ecological Economics 54 (1), 9-21.

Armstrong, W.G., 1863. Address'. Report of 33rd Meeting of the British Association for the Advancement of Science. London.

Bianchini, V., 2011. James Mill on Intemperance and Individual Preferences. 14th Summer School on History of Economic Thought, Economic Philosophy and Economic History. Institute of Social Sciences, Lisbon, 1-8 (September).

Black, R.D.C., Könekamp, R., 1972. Papers and Correspondence of William Stanley Jevons, vol.1. MacMillan, London.

Black, R.D.C., 1977a. Papers and Correspondence of William Stanley Jevons, vol.3. MacMillan, London.

Black, R.D.C., 1977b. Papers and Correspondence of William Stanley Jevons, vol.5. MacMillan, London.

Black, R.D.C., 1981. Papers and Correspondence of William Stanley Jevons, vol. 7, MacMillan, London.

Chaigneau, N., 2002. Jevons, Edgeworth et les "sensations subtiles du cœur humain": l'influence 
de la psychophysiologie sur l'économie marginaliste. Revue d'histoire des sciences humaines 7, 13-39.

Clark, B., Foster, J.B., 2001. William Stanley Jevons and The Coal Question: an introduction to Jevons's "Of the Economy of Fuel". Organization \& Environment 14 (1), 93-98.

Fine, B., 1990. The Coal Question. Political Economy and Industrial Change from the Nineteenth Century to the Present Day. Routledge, London.

Gaudet, G., 1984. Théorie économique et prévision en économie des ressources naturelles. L'actualité économique 60 (3), 271-279.

Georgescu-Roegen, N., 1975. Energy and Economic Myths. Southern Economic Journal 41 (3), 347-381.

Georgescu-Roegen, N., 1978. De la science économique à la bioéconomie. Revue d'économie politique. 88 (3), 337-382.

Gladstone, W.E., 1866. Letter to Mr Macmillan, in Black, R.D.C. and Könekamp, R. 1972. Papers and Correspondence of William Stanley Jevons, vol.1. MacMillan, London, p. 203.

Greening, L.A., Greene, D.L., Difiglio, C., 2000. Energy efficiency and consumption - the rebound effect - a survey. Energy Policy 28, 389-401.

Gowdy, J.M., O'Hara, S., 1997. Weak sustainability and viable technologies. Ecological Economics 22 (3), 239-247.

Hotelling, H., 1931. The economics of exhaustible resources. Journal of Political Economy 39 (2), 137-175.

Hull, E., 1861. The Coal-Fields of Great Britain: Their History, Structure, and Resources, second ed. Stanford, London.

Jevons, W.S., 1864. Letter to Herbert Jevons, in Black, R.D.C. 1977a. Papers and Correspondence of William Stanley Jevons, vol.3. MacMillan, London, p. 52.

Jevons, W.S., 1866a. Letter to Sir John F. Herschel, in Black, R.D.C. 1977a. Papers and Correspondence of William Stanley Jevons, vol.3. MacMillan, London, pp. 122-123.

Jevons, W.S., 1866b. The Coal Question: An
Inquiry Concerning the Progress of the Nation, and the Probable Exhaustion of our Coal Mines, second ed. MacMillan, London.

Jevons, W.S., 1867. On Coal. Lecture Delivered in the Carpenter's Hall of Manchester, in Black, R.D.C. 1981. Papers and Correspondence of William Stanley Jevons, vol.7. MacMillan, London, pp. 18-28.

Jevons, W.S., 1868. On the Probable Exhaustion of Our Coal Mines. Lecture Delivered at the Royal Institution, in Black, R.D.C. 1981. Papers and Correspondence of William Stanley Jevons, vol.7. MacMillan, London, pp. 28-35.

Jevons, W.S., 1871. Theory of Political Economy. MacMillan, London.

Jevons, W.S., 1875. On the Progress of the Coal Question. A Paper Read before Section F of the British Association for the Advancement of Science, in Black, R.D.C. 1981. Papers and Correspondence of William Stanley Jevons, vol.7. MacMillan, London, pp. 36-37.

Jevons, W.S., 1877. The Principles of Science: A Treatise on Logic and Scientific Method, second ed. MacMillan, London.

Maas, H., 2005. William Stanley Jevons and the Making of Modern Economics. Cambridge University Press, New-York.

Madlener, R., Alcott, B., 2009. Energy rebound and economic growth: a review of the main issues and research needs. Energy 34 (3), 370-376.

Malthus, T.R., 1820. Principles of Political Economy. 1989. Cambridge University Press, London.

Malthus, T.R., 1826. An Essay on the Principle of Population, sixth ed. John Murray, London.

Martinez-Alier, J., 1987. Ecological Economics Energy Environment and Society. Basil Blackwell, Oxford.

Mill, J.-S., 1866. Speech in front of the British Parliament on the Occasion of the Debates about Malt Duty. (Delivered on April, 17th). (Online accessed in February 2011 on http://hansard.millbanksystems.com/).

Mirowski, P., 1989. More Hear than Light. Economics as Social Physics, Physics as Nature's Economics. Cambridge University Press, 
Cambridge.

Pearce, D.W., 1997. Substitution and sustainability: some reflections on Georgescu- Roegen. Ecological Economics 22 (3), 295-297.

Pearce, D.W., Atkinson, G.D., 1993. Capital theory and the measurement of sustainably development: an indicator of "weak" sustainability. Ecological Economics 8 (2), 103-108.

Pearce, D.W., Atkinson, G.D., Dubourg, W.R., 1994. The economics of sustainable development. Annual Review Energy Environment 19, 457-474.

Peart, S., 1996. The Economics of W.S. Jevons. Routledge, London.

Peel, R., 1842. Parliamentary debates about coal duties (June, 13th) (Online accessed in December 2011 on http://hansard.millbanksystems.com).

Price-Williams, R., 1889. The coal question. Journal of the Royal Statistical Society 52 (1), 146.

Ricardo, D., 1821. Principles of Political Economy, The Works and Correspondence of David Ricardo, vol.I, ed. by Sraffa, P., 1953. Cambridge University Press, London.
Robine, M., 1990. La question charbonnière de William Stanley Jevons. Revue économique 41 (2), 369-394.

Sekerler-Richiardi, A.P., 2010. Jevons et Walras: entre philosophie morale et économie sociale, un jalon à la compréhension de la décision publique. Phd thesis. University of Paris 1 and University of Lausanne.

Sorrell, S., 2009. Jevons' Paradox revisited: the evidence for backfire from improved energy efficiency. Energy Policy 37 (4), 1456-1469.

van den Bergh, J.C.J.M., 2011. Energy conservation more effective with rebound policy. Environmental and Resource Economics 48 (1), 43-58.

Venkatachalam, L., 2007. Environmental economics and ecological economics: where they can converge? Ecological Economics 61, 550-558.

White, M.V., 1991. Frightening the "landed fogies": parliamentary politics and The Coal Question. Utilitas 3 (2), 289-302. 